\title{
Coexistence of seizure episodes and symptomatic sinoatrial arrest occurring in two sisters suggests an underlying cardioneuronal channelopathy
}

\author{
Gian Piero Carboni, ${ }^{1}$ Jacopo C DiFrancesco, ${ }^{2}$ Raffaella Milanesi, ${ }^{3}$ Mirko Baruscotti ${ }^{3}$
}

'Departmrnt of Nuclear Cardiology, Università Campus Bio-Medico, Rome, Italy ${ }^{2}$ Laboratory of Neurobiology, University of Milano-Bicocca, Monza (MB), Italy ${ }^{3}$ Dipartimento di Bioscienze, Università degli Studi di Milano, Milano, Italy

\section{Correspondence to}

Professor Gian Piero Carboni, g.carboni@unicampus.it
To cite: Carboni GP DiFrancesco JC, Milanesi $\mathrm{R}$, et al. BMJ Case Rep Published online: [please include Day Month Year] doi:10.1136/bcr-2013200577

\section{DESCRIPTION}

In February 2013, two sisters, aged 18 and 24, presented with a history of episodes of loss of consciousness (ELCOs) occurring since childhood. In the past 2 years, the ELCOs increased to an average of $10 /$ year, preceded by migraines and lasting at least $10 \mathrm{~min}$, with loss of postural control and slow recovery. The sisters also reported, brief lapses of consciousness. In 2010 and 2012, sleep-deprived EEG, during-sleep EEG, ambulatory EEG and a brain MRI, were all inconclusive for epilepsy. A nitrate-stimulated tilt test was followed by a brief ELCO in both girls, reflecting an uncertain diagnosis of vasovagal syncope, as the patients presented with pretest orthostatic hypotension. ${ }^{1}$ The finding of sinoatrial node arrest with ELCOs on Holter monitoring in the younger sister (figure 1) and on loop recording in the elder sister (figure 2) supported dual-chamber pacemaker implantation, in July 2012 and January 2013, respectively. Nevertheless, the ELCOs did not cease, and a neurological workup was again inconclusive. In May 2013, a patients' relative documented a seizure episode in the elder sister through a series of photographs and a video (figure 3 and video 1). These pictures might suggest a familial hemiplegic

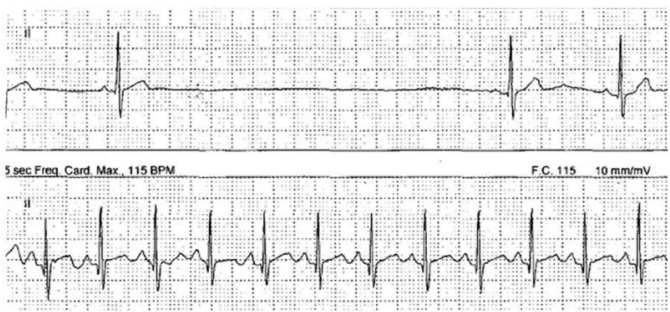

Figure 1 Episode of a $3.8 \mathrm{~s}$ sinoatrial node arrest, associated with an episodes of loss of consciousness and occurring in the younger sister, on a Holter monitoring recording.

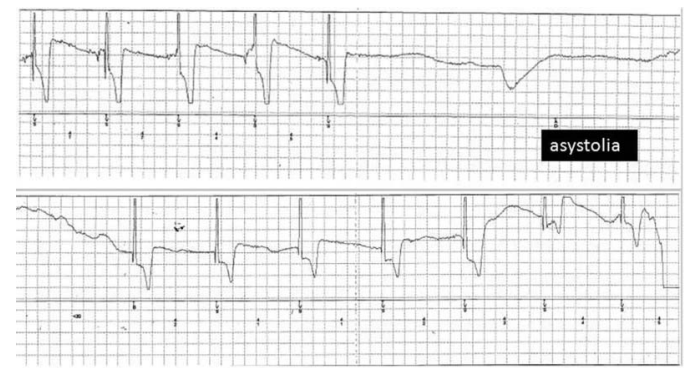

Figure 2 Episode of a $8.6 \mathrm{~s}$ sinoatrial node arrest, associated with an episodes of loss of consciousness and occurring in the elder sister, on a loop recording.

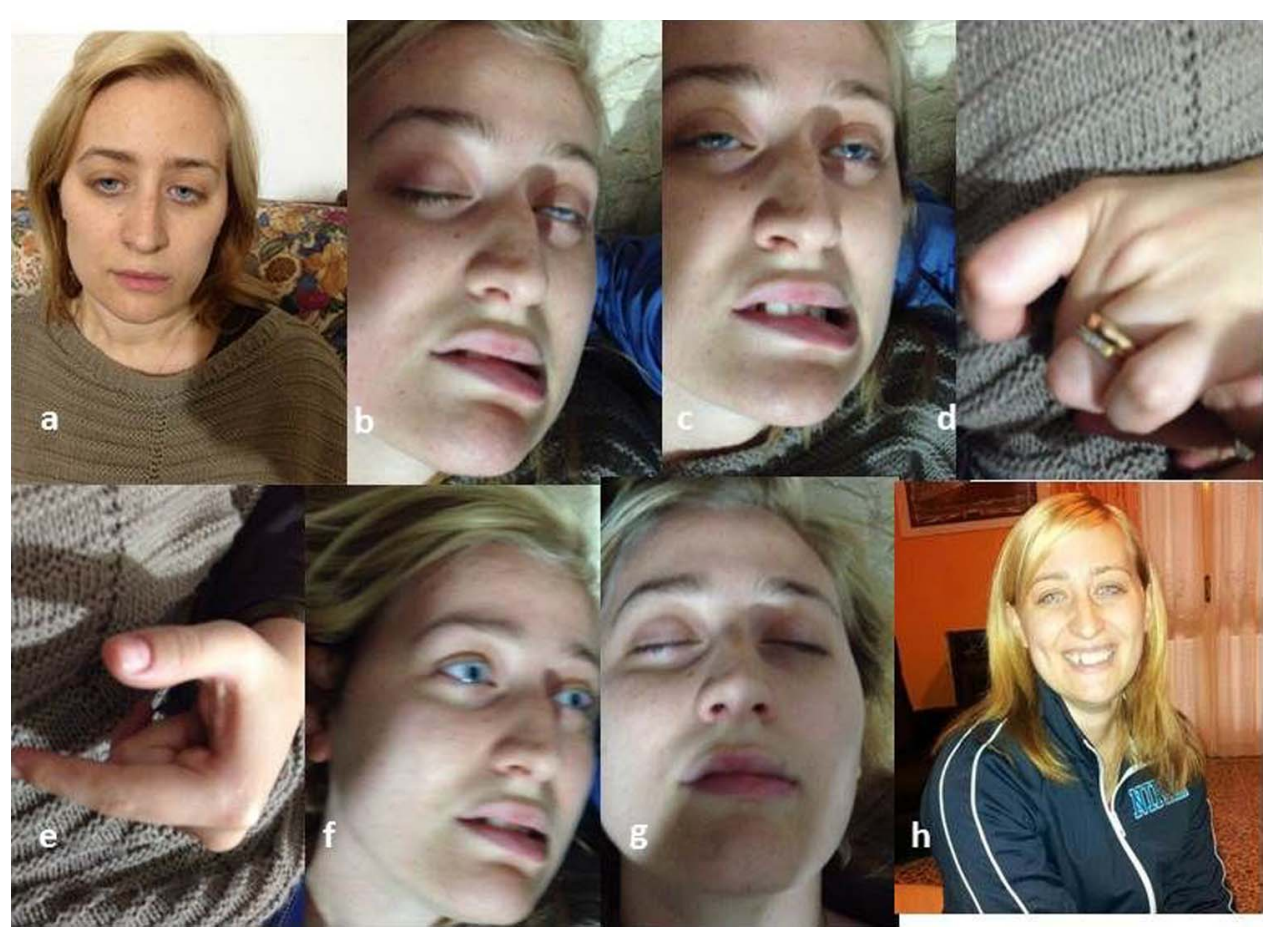

Figure 3 Series of photo shoots of the elder sister during the aura with migraine and profound feelings of fear (A) which precedes the seizure episode. She manifests mouth deviation to the left side ( $B$ and $C$ ), flexion/extension of the left hand (D and $E)$ and nystagmus (F). Recovery starts after $5 \mathrm{~min}(\mathrm{G})$. Complete recovery is achieved by up to $1 \mathrm{~h}(\mathrm{H})$. 


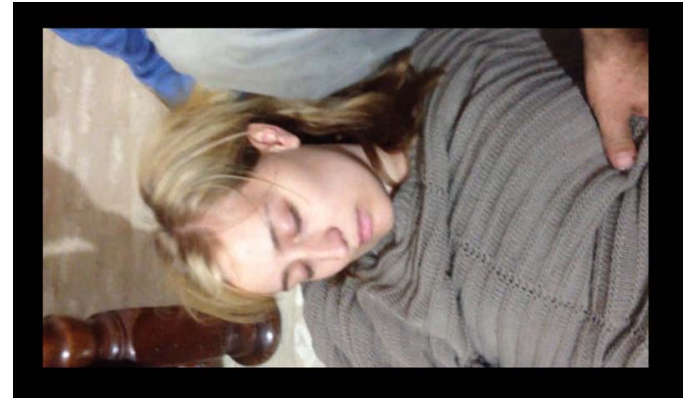

Video 1 A 5 min seizure episode regarding the elder sister. The patient is unable to maintain the upright position, so bystanders lay her down on the floor. She manifests mouth deviation to the left side, repetitive flexion/extension of the left hand and episodes of nystagmus. At the end of this episode, the patient could respond to her mother's solicitations only by nodding her head.

migraine. ${ }^{2}$ Nevertheless, the cardiac and neuronal symptoms are suggestive of a defect in cellular excitability, most likely a channellopathy. ${ }^{3}$ The screening of ion channel genes, including hyperpolarisation-activated cyclic nucleotide-gated (HCN) channels, might disclose the link between arrhythmias and seizures. ${ }^{4}$ This study and imaging techniques could explain important details of this disease. ${ }^{5} 6$

\section{Learning points}

The presence of migraine with aura, seizures and asystole, occurring in members of the same family, implies a diagnostic dilemma

- The relationship between seizures and arrhythmias may take diverse forms. Details of the patient's history and ictal recordings are critical:

- Arrhythmias can cause convulsive syncope;

- Seizures can cause arrhythmogenic epilepsy;

- Treatment of epilepsy can cause arrhythmias.

- Familial hemiplegic migraine (HM) is a rare entity, genetically heterogeneous and characterised by transient hemiparesis during attacks. The presence of additional symptoms such as aura and epilepsy has been described. Both girls of this report, presented with a history of migraine and seizures. However, the presence of asystole suggests an alternative underlying genetic disorder.

- Arrhythmias may be associated with abnormal cardiac channel function due to mutations in ion channel genes. Epilepsy is a disorder of neuronal function involving abnormal channel function. The finding of these disorders in the same family supports the emerging concept of a genetic determined cardioneuronal channelopathy.
The role of a genetic study for patients suspected of having a channelopathy needs some explanation:

hyperpolarisation-activated cyclic nucleotide-gated (HCN) genes code for a family of proteins representing the molecular correlates of native cardiac and neuronal ' $f$ ' $/$ ' $h$ ' channels. HCN channels are expressed in cardiac pacemaker cells where they underlie cardiac rhythm generation and rate modulation and in neurons where they control cell excitability. Defective HCN genes may therefore be a common pathway linking heart arrhythmias and brain seizures. Genetic screening for mutations in HCN channels is thus an important diagnostic tool which can help identify inheritable forms of cardioneuronal channelopathy.

- The 'invisible' lesions that are responsible for epilepsy could be detected by combining imaging techniques with metabolic and functional studies, including $18 \mathrm{~F}$ fluorodeoxyglucose-positron emission tomography, ictal single-photon emission CT, diffusion MRI and magnetic resonance spectroscopy.

Acknowledgements The author acknowledges Dr Vito Calabrese, cardiologist at the Campus Bio-Medico University of Rome, for the evaluation of the arrhythmias and pacemaker implantation.

Contributors GPC contributed by providing the patients clinical follow-up, he consulted diverse specialists and was involved in writing the manuscript. JCD, RM and $\mathrm{MB}$ made individual contributions to the writing of genetic section of the manuscript. They critically revised the manuscript, and confirmed that a genetic defect of ion channels, and particularly of HCN channels, could well justify the dual, cardiac and neuronal, nature of the disease. These scientists have thus planned a complete screening of ionic channel genes as the future direction for a molecular identification of the mechanism of the disease.

Competing interests None.

Patient consent Obtained.

Provenance and peer review Not commissioned; externally peer reviewed.

\section{REFERENCES}

1 Nwazue VC, Raj SR. Confounders of vasovagal syncope: orthostatic hypotension. Cardiol Clin 2013;31:89-100.

2 Pelzer N, Stam AH, Haan J, et al. Familial and sporadic hemiplegic migraine: diagnosis and treatment. Curr Treat Options Neurol 2013;15:13-27.

3 Baruscotti M, Bottelli G, Milanesi R, et al. HCN-related channelopathies. Pflugers Arch 2010;460:405-15.

4 Difrancesco J, Barbuti A, Milanesi R, et al. Recessive loss-of-function mutation in the pacemaker HCN2 channel causing increased neuronal excitability in a patient with idiopathic generalized epilepsy. J Neurosci 2011;31:17327-37.

5 Lüders HO, Amina S, Baumgartner $\mathrm{C}$, et al. Modern technology calls for a modern approach to classification of epileptic seizures and the epilepsies. Epilepsia 2012;53:405-11.

6 Cendes F. Nuroimaging in investigation of patients with epilepsy. Continuum (Minneap Minn) 2013;19:623-42. 
Copyright 2013 BMJ Publishing Group. All rights reserved. For permission to reuse any of this content visit http://group.bmj.com/group/rights-licensing/permissions.

BMJ Case Report Fellows may re-use this article for personal use and teaching without any further permission.

Become a Fellow of BMJ Case Reports today and you can:

- Submit as many cases as you like

- Enjoy fast sympathetic peer review and rapid publication of accepted articles

- Access all the published articles

- Re-use any of the published material for personal use and teaching without further permission

For information on Institutional Fellowships contact consortiasales@bmjgroup.com

Visit casereports.bmj.com for more articles like this and to become a Fellow 